\title{
Analisis Komparatif Kinerja Pemerintahan Daerah Se-Sumatera Bagian Selatan Berdasarkan Opini Badan Pemeriksa Keuangan
}

\author{
Verawaty \\ Universitas Bina Darma \\ Email:verawaty@binadarma.ac.id \\ M. Ibrahim Fikri \\ BPK RI Perwakilan Sumatera Selatan \\ Email: m.ibrahim_fikri@yahoo.com \\ Adithya Puspita Sari \\ Universitas Bina Darma \\ Email: adithyapuspitasari001@gmail.com \\ Citra Indah Merina \\ Universitas Bina Darma \\ Email: citraindah@binadarma.ac.id
}

\begin{abstract}
The performance of the administration of local government describes the work performance that can be achieved during a period. The performance of those that gets Unqualified Opinion (UQ) should be better than those with Qualified Opinion (QO). This study was aimed to compare the performance of regional government in Southern Sumatera which obtained UQ and OQ for the observed period. The object was 60 local governments in Southern Sumatera. Hypothesis testing used the Mann Whitney Test. The test results showed that there were differences in performance between the regional governments that obtained UQ and OQ by using the Pure Participation Rate (PPR) as the indicator. This means, those that obtained UQ were more successful in providing services to the community, especially in the field of education. However, there were no differences by using the Gross Regional Domestic Product (GRDP), capital expenditure, Performance Evaluation Local Government Administration (PELGA), and Human Achievement Index (HDI) as the indicators. Research implications for local governments, are expected to be able to improve the performance, especially in the field of finance by increasing detection of regional revenue sources and being able to manage them well.
\end{abstract}

Keywords: Audit Opinion, Performance of Regional Government

\begin{abstract}
Abstrak
Kinerja penyelenggaraan pemerintahan daerah merupakan sebuah bentuk gambaran dari prestasi kerja yang dapat dicapai selama periode tertentu. Kinerja penyelenggaraan pemerintahan daerah yang mendapatkan Opini WTP semestinya lebih baik dari yang Non WTP. Penelitian ini bertujuan untuk membandingkan kinerja penyelenggaraan pemerintahan daerah di Sumatera Bagian Selatan yang memperoleh opini WTP dan Non WTP untuk periode 2015-2016. Objek penelitian ini, yaitu 60 pemerintah daerah kabupaten/kota di Sumatera Bagian Selatan. Pengujian hipotesis menggunakan Mann Whitney Test. Hasil pengujian menunjukkan bahwa terdapat perbedaan kinerja penyelenggaraan antara pemerintah daerah yang memperoleh opini WTP dan Non WTP dengan menggunakan Angka Partisipasi Murni (APM). Hal ini berarti, pemerintah daerah yang memperoleh opini WTP lebih berhasil dalam memberikan pelayanan kepada masyarakat khususnya di bidang pendidikan. Namun tidak terdapat perbedaan kinerja penyelenggaraan antara pemerintah daerah yang memperoleh opini WTP dan Non WTP dengan menggunakan Produk Domestik Regional Bruto (PDRB), belanja modal, Evaluasi Kinerja Penyelenggaraan Pemerintahan Daerah (EKPPD), dan Indeks Prestasi Manusia (IPM). Implikasi penelitian bagi pemerintah daerah, yaitu diharapkan untuk dapat meningkatkan kinerja pemerintahan daerahnya terutama dalam bidang keuangannya dengan meningkatkan pendeteksian terhadap sumber-sumber pendapatan daerah serta mampu mengelolanya dengan baik.
\end{abstract}

Kata Kunci: Opini Audit, Kinerja Penyelenggaraan Pemerintahan Daerah 


\section{Pendahuluan}

Luasnya wilayah negara Republik Indonesia, menyebabkan ketidakmungkinan bagi pemerintah pusat untuk mengurus semua kepentingan masing-masing daerah secara langsung. Saat ini Indonesia sendiri memiliki 34 provinsi, dengan kabupaten yang berjumlah 397 dan kota berjumlah 93 (Kepmendagri, 2018). Dengan jumlah daerah otonom sebanyak 409 tersebut, maka tidak mungkin pemerintah pusat mampu mengurus segala kepentingan masing-masing daerah dalam waktu yang bersamaan. Untuk mengoptimalkan penyelenggaraan pemerintahan dalam mengurus kepentingan masing-masing daerahnya, maka pemerintah pusat turut melibatkan campur tangan pemerintah daerah. Ini menunjukkan tingkat kewenangan dan tanggung jawab yang diberikan pemerintah pusat kepada pemerintah daerah untuk melaksanakan pembangunan (Verawaty, 2017).

Pemerintah daerah sesuai dengan pasal 1 poin 2 Undang-Undang Nomor 23 Tahun 2014 tentang Pemerintahan Daerah, merupakan penyelenggaraan urusan pemerintahan oleh pemerintah daerah dan Dewan Perwakilan Rakyat Daerah (DPRD) menurut asas otonomi dan tugas pembantuan dengan prinsip otonomi seluas-luasnya dalam sistem dan prinsip Negara Kesatuan Republik Indonesia (NKRI) sebagaimana dimaksud dalam Undang-Undang Dasar Negara Republik Indonesia Tahun 1945. Pemerintah daerah telah diberi kewenangan yang luas dalam menyelenggarakan pemerintahan bersama DPRD mulai dari perencanaan, pelaksanaan, pengawasan, pengendalian dan evaluasi yang berhubungan dengan kepentingan daerahnya sendiri. Dalam hal ini terlihat bahwa telah terjadinya desentralisasi. Hal ini sesuai dengan Undang-Undang Nomor 22 Tahun 1999 tentang Otonomi Daerah, yang mana pemerintah pusat telah menyerahkan urusan pemerintahan kepada pemerintah daerah sehingga terbentuknya hak otonomi daerah.

Sesuai dengan pasal 1 poin 6 Undang-Undang Nomor 23 Tahun 2014 tentang Pemerintahan Daerah, mengartikan otonomi daerah sebagai hak, wewenang dan kewajiban daerah otonom untuk mengatur dan mengurus sendiri urusan pemerintahan dan kepentingan masyarakat setempat dalam sistem NKRI. Pemerintah daerah bertanggung jawab untuk mengoptimalkan pelayanannya terhadap kepentingan masyarakat baik menyangkut keamanan, ketertiban, kesejahteraan sosial, pendidikan serta berbagai sarana/prasarana bagi kepentingan umum. Untuk dapat memenuhi hal tersebut, pemerintah daerah juga membutuhkan dana yang di dalam Laporan Keuangan Pemerintah Daerah (LKPD) dicantumkan sebagai pendapatan dan dikategorikan menjadi; Pendapatan Asli Daerah (PAD), pendapatan transfer, dan lain-lain pendapatan yang sah. Pendapatan transfer diperoleh pemerintah daerah dari pemerintah pusat, yang bersumber dari Anggaran Pendapatan Belanja Negara (APBN). Hal ini menandakan bahwa dana yang digunakan oleh pemerintah daerah untuk kepentingan daerahnya tidak sepenuhnya berasal dari daerah itu sendiri, melainkan adanya keikutsertaan pemerintah pusat yang ditandai dengan adanya bantuan "dana transfer" (Verawaty dkk., 2020) sehingga pemerintah daerah harus memberikan bentuk pertanggungjawabannya dalam mengelola dana tersebut berupa LKPD yang telah diaudit oleh Badan Pemeriksa Keuangan (BPK). Laporan keuangan perlu diaudit terlebih dahulu serta harus dilampiri dengan pengungkapan karena laporan keuangan merupakan salah satu bentuk mekanisme pertanggungjawaban dan sebagai dasar untuk pengambilan keputusan bagi pihak yang berkepentingan terhadap hasilnya (Verawaty, 2017).

Opini audit merupakan bentuk hasil pemeriksaan BPK terhadap LKPD. Opini audit BPK terdiri dari opini; (1) Wajar Tanpa Pengecualian/WTP (Unqualified Opinion), (2) Wajar Dengan Pengecualian/WDP (Qualified Opinion), (3) Tidak Wajar/TW (Adversed Opinion), (4) Tidak Menyatakan Pendapat/TMP (Disclaimer of Opinion). Opini WTP merupakan opini terbaik dari BPK yang menandakan bahwa laporan keuangan telah bebas dari kesalahan-kesalahan atau kekeliruan yang material, yang didasarkan pada bukti-bukti audit yang dikumpulkan. Menurut 
Undang-Undang Nomor 15 Tahun 2004 tentang Pemeriksaan Pengelolaan dan Tanggung Jawab Keuangan Negara, opini audit merupakan pernyataan profesional sebagai kesimpulan pemeriksa mengenai tingkat kewajaran informasi yang disajikan dalam laporan keuangan yang didasarkan pada; (1) Kesesuaian dengan standar akuntansi pemerintah, (2) Kecukupan pengungkapan, (3) Kepatuhan terhadap peraturan per Undang-Undangan dan (4) Efektivitas Sistem Pengendalian Intern (SPI). Berdasarkan keempat dasar tersebut, dapat disimpulkan jika opini BPK hanya mengungkapkan kualitas dari laporan keuangan, bukan kinerja dari pemerintah daerah dalam menyelenggarakan pemerintahannya.

Kinerja penyelenggaraan pemerintahan daerah merupakan sebuah bentuk gambaran dari hasil atau prestasi kerja yang dapat dicapai oleh pemerintah daerah itu sendiri pada periode tertentu. Kinerja penyelenggaraan pemerintahan daerah yang mendapatkan Opini WTP semestinya lebih baik dari yang Non WTP. Opini WTP merupakan opini tertinggi yang menggambarkan laporan keuangan telah memiliki kualitas terbaik, hal ini menandakan bahwa pemerintah daerah dengan opini WTP memiliki kinerja keuangan yang baik. Dengan baiknya kinerja keuangan pemerintah tersebut, seharusnya kinerja penyelenggaraan pemerintahannya pun juga membaik, karena danadana di dalam APBD telah tersalurkan sebagaimana mestinya.

Hasil opini BPK merupakan suatu hal yang menarik untuk dipelajari lebih lanjut, karena banyak pemerintah daerah di Indonesia yang mendapatkan opini WTP, tetapi terbukti melakukan penyelewengan. Seperti fenomena-fenomena yang terjadi belakangan ini, dengan terungkapnya berbagai kasus-kasus penyelewengan anggaran oleh instansi pemerintah yang memperoleh opini yang baik menyebabkan opini BPK diragukan.

Korupsi merupakan bukti penyebab terhambatnya tata kelola yang baik atau good governance (Verawaty dkk., 2019). Dimulai dari tahun 2013, menurut hasil penyidikan Komisi Pemberantasan Korupsi (KPK), negara telah mengalami kerugian sebesar Rp 471 miliar dalam proyek pembangunan sarana olahraga terpadu di Hambalang Bogor yang dilakukan oleh Kementrian Pemuda dan Olahraga (memperoleh opini WDP). Tahun 2016, bekas auditor BPK Provinsi Sulawesi Utara, terbukti meloloskan hasil pemeriksaan sejumlah pemerintah kabupaten/kota di Sulawesi Utara dengan memintai dana hingga Rp 1,6 miliar. Di tahun yang sama, juga terjadi penyelewengan kasus jual beli opini BPK pada Kementrian Desa, Pembangunan Daerah Tertinggal dan Transmigrasi, sehingga auditor BPK ditangkap KPK karena diduga menerima suap (Kompas, 31/05/2017).

Dengan berbagai kasus tersebut, membuat terkikisnya kepercayaan masyarakat terhadap BPK, hal ini juga menimbulkan kecurigaan kepada institusi yang mendapatkan predikat WTP, apakah diperoleh dengan wajar atau tidak (Kompas, 31/05/2017). Opini WTP merupakan opini tertinggi yang diberikan oleh BPK, yang menandakan bahwa laporan keuangan yang diterbitkan pemerintah daerah telah memberikan informasi yang bebas dari salah saji, sehingga ini merupakan sebuah tolak ukur keberhasilan pemerintah daerah dalam mengelola anggarannya. Dengan pengelolaan anggaran yang baik, semestinya kinerja penyelenggaraan dari pemerintah daerah tersebut juga baik. Verawaty (2014) menyimpulkan bahwa akuntabilitas atas suatu anggaran yang meningkat, pemerintah daerah pasti akan menghadapi peningkatan permintaan untuk memantau informasi dan insentif yang lebih besar untuk memberi sinyal kinerja. Namun ternyata, belakangan ini banyak ditemukan oknum-oknum yang melakukan penyelewenganpenyelewengan, agar laporan keuangan yang mereka sajikan dapat memperoleh opini WTP dari BPK. Hal ini menyebabkan kelayakan opini WTP pun masih perlu dipertanyakan. Tidak tanggung-tanggung, mereka berani menyuap auditor yang menjadi kepercayaan publik dalam memeriksa laporan keuangannya. Hal ini tentunya telah membuat kepercayaan publik menurun terhadap opini WTP yang diberikan BPK, apakah memang benar-benar WTP atau tidak. 
Untuk penyelewengan yang terjadi di Sumatera Bagian Selatan ini, para aparat daerah tersebut telah ditetapkan sebagai tersangka. Berdasarkan Pasal 1 angka 14 Kitab Undang-Undang Hukum Pidana (KUHP), yang dimaksud dengan tersangka adalah seorang yang karena perbuatannya atau keadaannya berdasarkan bukti permulaan patut diduga sebagai pelaku tindak pidana. Hal ini menandakan bahwa telah ditemukannya bukti-bukti penyelewengan terhadap aparat negara tersebut, sehingga patut diduga telah melakukan penyelewengan terhadap dana yang seharusnya digunakan untuk kepentingan masyarakat, tetapi malah digunakan untuk kepentingan pribadi atau kelompok tertentu. Jika dilihat ternyata pemerintah provinsi tersebut, pada saat itu memperoleh opini WTP dan WDP yang artinya kualitas laporan keuangan mereka telah masuk ke dalam kategori "baik", yang menandakan angka-angka yang disajikan telah sesuai dengan bukti-bukti pendukungnya. Jika mengingat adanya bukti permulaan sehingga ditetapkan sebagai tersangka, maka hal ini juga patut dipertanyakan seperti halnya kasus-kasus suap opini BPK yang telah dijelaskan sebelumnya, apakah opini WTP yang diberikan benar-benar WTP atau tidak.

Opini BPK merupakan salah satu dasar yang dapat menggambarkan kualitas keuangan pemerintah daerah. Melalui opini BPK, seharusnya kinerja penyelenggaraan pemerintahan daerah juga dapat tergambarkan baik buruknya. Dengan melihat kualitas keuangan yang baik, sudah sepantasnya pemerintah daerah tersebut dapat menghasilkan kinerja penyelenggaraan pemerintahan yang baik pula. Namun dengan ditemukan berbagai kasus mengenai penyelewengan yang berkaitan dengan opini BPK dan APBD belakangan ini, membuat opini BPK perlu dipertanyakan kembali, oleh sebab itu perlu dilakukannya perbandingan terhadap kinerja penyelenggaraan pemerintahan daerah, baik yang memperoleh opini WTP maupun Non WTP.

Perbandingan terhadap kinerja penyelenggaraan pemerintahan daerah yang memperoleh opini WTP dan Non WTP merupakan suatu hal yang sangat penting untuk dilakukan. Dengan membandingkan kinerja penyelenggaraan pemerintahan daerah terhadap dua kelompok pemerintah daerah tersebut, publik dapat mengetahui bagaimana pemerintah daerah dalam menjalankan tugas dan wewenang yang telah dilimpahkan kepadanya untuk mengurus segala kepentingan daerahnya masing-masing, demi meningkatkan kesejahteraan masyarakat. Jika untuk melihat kualitas laporan keuangan pemerintah daerah dapat menggunakan LKPD yang telah diaudit oleh BPK, maka untuk melihat kinerja penyelenggaraan pemerintahan daerah dapat melalui kinerja pembangunan daerah itu sendiri, seperti dalam hal perekonomian daerahnya, bagaimana keuangan daerahnya, bentuk pelayanan publik yang diberikan, kinerja aparatur pemerintah daerahnya dan yang terpenting adalah bagaimana kesejahteraan masyarakat di daerah tersebut (Bappenas, 2014). Dalam penelitian ini menggunakan Produk Domestik Regional Bruto (PDRB), belanja modal, Angka Partisipasi Murni (APM), Evaluasi Kinerja Penyelenggaraan Pemerintahan Daerah (EKPPD), dan Indeks Prestasi Manusia (IPM) yang dipilih sebagai indikator dalam membandingkan kinerja penyelenggaraan pemerintahan daerah.

\section{Kajian Pustaka}

\subsection{Teori Stakeholder (Stakeholder Theory)}

Stakeholder theory merupakan teori yang menyatakan bahwa perusahaan bukanlah entitas yang hanya beroperasi untuk kepentingan sendiri, tetapi harus memberikan manfaat kepada seluruh stakeholder-nya (Ghozali dan Chariri, 2007), sedangkan menurut Freeman dan Vea, (2001) dalam Yasmin (2016), stakeholder theory adalah teori yang menggambarkan kepada pihak mana saja atau stakeholder suatu organisasi bertanggung jawab. Dengan menggunakan definisi di atas, stakeholder theory tidak hanya diperuntukkan bagi organisasi swasta semata tetapi juga dapat ditujukan kepada organisasi sektor publik (pemerintah). 
Pemerintah daerah dalam menjalankan tanggung jawabnya perlu memperhatikan para stakeholder. Pemerintah daerah beroperasi bukan hanya untuk kepentingannya sendiri, melainkan juga harus dapat memberikan manfaat kepada para stakeholder-nya, seperti masyarakat dan pemerintah pusat. Pemerintah pusat ataupun masyarakat memiliki hak untuk memperoleh informasi mengenai operasional pemerintah daerah, yang dapat mempengaruhi pengambilan keputusan mereka.

Pemerintah daerah harus dapat menyajikan laporan keuangannya secara transparan dan akuntabel, sebagai bentuk pertanggungjawaban kepada publik. Hal ini sesuai dengan amanat yang terkandung dalam Undang-Undang Nomor 17 Tahun 2013 tentang Keuangan Negara, menyebutkan bahwa presiden ataupun kepala daerah (Gubernur/bupati/walikota) diwajibkan untuk menyampaikan pertanggungjawaban APBN/APBD kepada DPR/DPRD dalam bentuk laporan keuangan yang telah diaudit oleh BPK sebelumnya, dengan waktu selambat-lambatnya enam (6) bulan setelah tahun anggaran berakhir. Selain itu, sesuai dengan Peraturan Pemerintah Nomor 3 Tahun 2007 tentang Laporan Penyelenggaraan Pemerintah Daerah kepada Pemerintah, Laporan Keterangan Pertanggungjawaban Kepala Daerah kepada Dewan Perwakilan Rakyat Daerah, dan Informasi Laporan Penyelenggaraan Pemerintahan Daerah Kepada Masyarakat, menyatakan bahwa pemerintah daerah juga diwajibkan memberikan laporan keuangan yang berisikan informasi-informasi mengenai penyelenggaraan pemerintahan daerah terkait dengan urusan desentralisasi, tugas pembantuan dan tugas umum pemerintah.

Dengan adanya dua dasar hukum, yaitu Undang-Undang Nomor 17 Tahun 2013 dan Peraturan Pemerintah Nomor 3 Tahun 2007 ini, maka dapat disimpulkan bahwa pemerintah daerah bertanggung jawab untuk menyajikan laporan keuangan dan laporan penyelenggaraannya sehingga stakeholder dapat mengetahui bagaimana kinerja pemerintah daerah dalam menjalankan tugas yang diberikan oleh pemerintah pusat.

\subsection{Hipotesis Penelitian}

H1: PDRB pemerintah daerah kabupaten/kota yang memperoleh opini WTP lebih tinggi dari pemerintah daerah yang beropini Non WTP.

$\mathrm{H} 2$ : Belanja modal pemerintah daerah kabupaten/kota yang memperoleh opini WTP lebih tinggi dari yang beropini Non WTP.

H3: APM pemerintah daerah kabupaten/kota yang memperoleh opini WTP lebih tinggi dari yang beropini Non WTP.

H4: EKPPD pemerintah daerah kabupaten/kota yang memperoleh opini WTP lebih tinggi dari yang beropini Non WTP.

H5: IPM pemerintah daerah kabupaten/kota yang memperoleh opini WTP lebih tinggi dari yang beropini Non WTP.

\section{Metode Penelitian}

\subsection{Populasi dan Teknik Pengambilan Sampel}

Populasi menurut Sugiyono (2016) adalah wilayah generalisasi yang terdiri dari atas subjek atau objek yang mempunyai kualitas dan karakteristik tertentu yang diterapkan oleh peneliti untuk dipelajari dan kemudian ditarik kesimpulannya. Populasi penelitian ini adalah seluruh pemerintah daerah kabupaten/kota se-Sumatera Bagian Selatan sampai tahun 2018 yang berjumlah 60 pemerintah daerah.

Sampel adalah sebagian dari jumlah dan karakteristik yang dimiliki oleh populasi tersebut, ataupun bagian kecil dari anggota populasi yang diambil menurut prosedur tertentu sehingga dapat mewakili populasinya. Teknik pengambilan sampel dilakukan dengan cara purposive 
sampling dengan tujuan untuk mendapatkan sampel yang representatif sesuai dengan kriteria yang ditentukan. Adapun kriteria yang digunakan untuk memilih sampel adalah sebagai berikut: 1. Merupakan pemerintah daerah kabupaten/kota se-Sumatera Bagian Selatan

2. Memiliki kelengkapan data dan informasi mengenai variabel-variabel yang diteliti.

Berdasarkan kriteria tersebut, hanya ada 53 pemerintah daerah kabupaten/kota yang memenuhi kriteria, sehingga sampel yang akan digunakan dalam penelitian ini, yaitu sebanyak 53 pemerintah daerah kabupaten/kota se-Sumatera Bagian Selatan.

\subsection{Sumber dan Teknik Pengumpulan Data}

Penelitian ini menggunakan metode dokumentasi. Metode dokumentasi adalah metode yang digunakan untuk mencari mengumpulkan, mencatat, dan mengkaji data mengenai hal-hal atau variabel berupa catatan, dokumen, transkrip, buku, surat kabar, majalah, jurnal, website, dan sebagainya. Hal ini bertujuan untuk mengumpulkan semua data yang diperlukan dalam penelitian untuk menjawab permasalahan penelitian dan memperkaya literatur untuk menunjang data kuantitatif yang diperoleh.

Penelitian ini menggunakan data sekunder, yaitu sumber yang tidak langsung memberikan data kepada pengumpul data, misalnya melalui orang lain atau lewat dokumen (Sugiyono, 2016). Adapun data sekunder yang digunakan dalam penelitian ini, yaitu:

1. Hasil pemeriksaan BPK, yaitu Ikhtisar Hasil Pemeriksaan Semester (IHPS) II tahun 2017, berupa opini BPK tahun 2015 dan 2016 untuk seluruh pemerintah daerah kabupaten/kota seSumatera Bagian Selatan, yang diperoleh dari website BPK (www.bpk.go.id).

2. Hasil perhitungan dari BPS, berupa nilai PDRB per kapita kabupaten/kota se-Sumatera Bagian Selatan tahun 2015 dan 2016 yang diperoleh dari website BPS (www.bps.go.id).

3. Laporan Realisasi APBD tahun 2015 dan 2016, berupa data belanja modal pemerintah daerah kabupaten/kota se-Sumatera Bagian Selatan yang diperoleh dari website DJP Kemenkeu (www.djpk.kemenkeu.go.id).

4. Data nilai APM tahun 2015 dan 2016 untuk pemerintah daerah kabupaten/kota se-Sumatera Bagian Selatan yang diperoleh dari website Kemendikbud (www.kemendikbud.go.id).

5. Hasil Kepmendagri RI Nomor 120-10421 tahun 2016 dan Kepmendagri RI Nomor 100-53 Tahun 2018, tentang Penetapan Peringkat dan Status Kinerja Penyelenggaraan Pemerintahan Daerah Secara Nasional Tahun 2015, berupa skor EKPPD untuk seluruh pemerintah daerah kabupaten/kota se-Sumatera Bagian Selatan yang diperoleh dari website Kemendagri (www.kemendagri.go.id).

6. Hasil perhitungan dari BPS, berupa nilai IPM pemerintah daerah kabupaten/kota se-Sumatera Bagian Selatan tahun 2016 yang juga diperoleh dari website BPS (www.bps.go.id).

\subsection{Teknik Analisis Data}

Metode dalam penelitian ini menggunakan teknik analisis komparasional. Analisis komparasional merupakan analisis data yang bersifat hubungan perbedaan antara variabel yang satu dengan yang lainnya atau antara fakta yang satu dengan yang lainnya. Analisis yang digunakan adalah MannWhitney Test merupakan teknik analisis nonparametrik yang digunakan untuk menguji hipotesis komparatif dua sampel independen. Uji Mann-Whitney digunakan untuk menguji signifikansi hipotesis komparatif dua sampel independen apabila datanya berbentuk ordinal. Tujuan uji MannWhitney adalah untuk membandingkan rata-rata dua sampel yang tidak berhubungan, memiliki nilai yang sama atau tidak. 


\section{Hasil dan Pembahasan}

\subsection{Hasil Uji Mann Whitney Test}

Kinerja pemerintah daerah dapat dibandingkan melalui masalah perekonomian, keuangan, pelayanan yang diberikan, kinerja masing-masing aparatur daerah dan kesejahteraan masyarakatnya. PDRB, belanja modal, APM, EKPPD dan IPM merupakan variabel yang dapat mewakili kelima permasalahan tersebut. Adapun tujuan dari pengujian hipotesis dengan menggunakan uji Mann Whitney Test terhadap variabel PDRB, belanja modal, APM, EKPPD dan IPM ini adalah untuk mengetahui perbandingan kinerja penyelenggaraan pemerintahan daerah yang memperoleh opini WTP dengan Non WTP. Adapun hasil dari pengujian hipotesis dengan menggunakan kelima variabel pembanding ini adalah sebagai berikut:

Tabel 1. Pengujian Mann Whitney Test

\begin{tabular}{|c|c|c|c|c|}
\hline \multicolumn{5}{|c|}{ Ranks } \\
\hline & Opini & $\mathrm{N}$ & Mean Rank & Sum of Ranks \\
\hline \multirow[t]{3}{*}{ PDRB } & Non WTP & 44 & 57,05 & 2510,00 \\
\hline & WTP & 62 & 50,98 & 3161,00 \\
\hline & Total & 106 & & \\
\hline \multirow[t]{3}{*}{ BM } & Non WTP & 44 & 50,98 & 2243,00 \\
\hline & WTP & 62 & 55,29 & 3428,00 \\
\hline & Total & 106 & & \\
\hline \multirow[t]{3}{*}{ APM } & Non WTP & 44 & 45,91 & 2020,00 \\
\hline & WTP & 62 & 58,89 & 3651,00 \\
\hline & Total & 106 & & \\
\hline \multirow[t]{3}{*}{ EKPPD } & Non WTP & 44 & 48,18 & 2120,00 \\
\hline & WTP & 62 & 57,27 & 3551,00 \\
\hline & Total & 106 & & \\
\hline \multirow[t]{3}{*}{ IPM } & Non WTP & 44 & 53,60 & 2358,50 \\
\hline & WTP & 62 & 53,43 & 3312,50 \\
\hline & Total & 106 & & \\
\hline
\end{tabular}

\begin{tabular}{|l|r|r|r|r|r|}
\hline \multicolumn{7}{|c|}{ Test Statistics $^{\mathbf{a}}$} \\
\hline & \multicolumn{1}{|c|}{ PDRB } & \multicolumn{1}{|c|}{ BM } & \multicolumn{1}{c|}{ APM } & \multicolumn{1}{c|}{ EKPPD } & \multicolumn{1}{c|}{ IPM } \\
\hline Mann-Whitney U & 1208,000 & 1253,000 & 1030,000 & 1130,000 & 1359,500 \\
\hline Wilcoxon W & 3161,000 & 2243,000 & 2020,000 & 2120,000 & 3312,500 \\
\hline Z & $-1,000$ &,- 712 & $-2,142$ & $-1,501$ &,- 029 \\
\hline Asymp. Sig. (2-tailed) &, 317 &, 477 &, 032 &, 133 &, 977 \\
\hline
\end{tabular}

Sumber: Data Diolah, 2020

Berdasarkan Tabel 1, terdapat satu variabel yang signifikan, yaitu APM. Artinya, hasil penelitian ini menunjukkan bahwa terdapat perbedaan kinerja penyelenggaraan pemerintahan antara pemerintah daerah kabupaten/kota se-Sumatera Bagian Selatan yang memperoleh opini WTP dengan Non WTP dengan menggunakan indikator APM, sedangkan untuk variabel lainnya, yaitu PDRB, belanja modal, EKPPD dan IPM tidak signifikan. Artinya hasil penelitian ini menunjukkan bahwa tidak terdapat perbedaan kinerja penyelenggaraan pemerintahan antara pemerintah daerah kabupaten/kota se-Sumatera Bagian Selatan yang memperoleh opini WTP dengan Non WTP dengan menggunakan indikator PDRB, belanja modal, EKPPD dan IPM. 


\subsection{Pembahasan}

\subsubsection{Perbedaan nilai PDRB pada pemerintah daerah kabupaten/kota yang beropini WTP dan Non WTP}

Hasil pengujian hipotesis pertama menunjukkan bahwa hipotesis pertama ditolak. Hasil pengujian pada Tabel 1, diperoleh nilai signifikansi (2-tailed) untuk variabel PDRB sebesar 0,317, dimana nilai tersebut lebih besar dari $0,05(\alpha=5 \%)$. Hasil pengujian untuk hipotesis pertama menunjukkan bahwa tidak ada perbedaan kinerja penyelenggaraan pemerintahan daerah untuk kabupaten/kota se-Sumatera Bagian Selatan, antara pemerintah daerah kabupaten/kota yang memperoleh opini WTP dan Non WTP yang diukur dari indikator PDRB. Hasil analisis ini tidak konsisten dengan hasil penelitian Yasmin (2016), yang menyatakan bahwa Kinerja Pemerintah Kabupaten/Kota se-Indonesia yang beropini WTP dengan indikator PDRB berbeda secara signifikan dengan Pemerintah Kabupaten/Kota se-Indonesia yang Non WTP.

Kinerja penyelenggaraan pemerintahan daerah kabupaten/kota se-Sumatera Bagian Selatan yang memperoleh opini WTP dengan indikator pertumbuhan ekonomi, yaitu PDRB tidak berbeda dengan yang memperoleh opini Non WTP, dikarenakan jumlah pengeluaran yang dikeluarkan oleh pemerintah daerah kabupaten/kota se-Sumatera Bagian Selatan untuk memenuhi kebutuhan masyarakat setempat periode 2015-2016 tidak jauh berbeda. Pengeluaran yang digunakan dalam memenuhi kebutuhan masyarakat ini memiliki kaitan dengan tingkat PDRB suatu daerah. Pengeluaran yang dilakukan oleh pemerintah daerah akan digunakan untuk memenuhi kepentingan masyarakat seperti untuk melaksanakan suatu proyek dalam hal pembangunan gedung, jalan, jembatan, pembelian alat transportasi dan sebagainya, yang mana hal ini dapat memberikan pengaruh terhadap produktivitas masyarakat. Ketika pembangunan dilakukan, pemerintah akan membutuhkan tenaga ahli ataupun alat-alat berat tertentu yang dapat menunjang pembangunan tersebut, yang dalam hal ini bisa disebut dengan jasa. Selain jasa yang dibutuhkan dalam pembangunan proyek tersebut, pemerintah daerah pastinya juga akan membutuhkan material atau bahan-bahan yang akan digunakan dalam pembangunan, hal ini akan membuat produktivitas terhadap barang di daerah setempat akan meningkat. Jadi dapat disimpulkan bahwa ketika jumlah pengeluaran yang dilakukan oleh suatu pemerintah daerah itu tinggi, yang akan digunakan untuk menjalankan sebuah proyek di daerah setempat akan melibatkan produktivitas, baik jasa maupun barang di daerah tersebut, sebagai akibat dari adanya permintaan akan barang dan jasa yang dibutuhkan untuk pembangunan proyek di daerah tersebut.

Verawaty (2017), menyatakan APBD yang sehat dalam hal ini tidak defisit, akan mendukung pencapaian target-target pembangunan secara optimal. Jika dilihat pada laporan realisasi APBD untuk pemerintahan daerah kabupaten/kota se-Sumatera Bagian Selatan tahun 2015 dan 2016, jumlah pengeluaran yang digunakan untuk pembangunan untuk masing-masing pemerintah daerah kabupaten/kota berkisar antara 1-5 ratus miliar rupiah, yang kebanyakan dari pemerintah daerahnya rata-rata mengeluarkan dana sekitar Rp 200-an miliar. Oleh karena jumlah pengeluaran yang digunakan untuk pembangunan dari masing-masing pemerintah daerah kabupaten/kota yang hampir sama, menyebabkan jumlah permintaan akan barang dan jasa pun hampir sama, hal ini menyebabkan jumlah barang dan jasa yang dihasilkan di daerah tersebut, yaitu tingkat PDRB masing-masing kabupaten/kota juga sama atau dengan kata lain tidak terdapat perbedaan tingkat PDRB untuk pemerintahan daerah kabupaten/kota se-Sumatera Bagian Selatan. Selain akibat dari adanya jumlah permintaan barang dan jasa yang sama, terdapat faktor lain yang juga menyebabkan tingkat PDRB kabupaten/kota tidak terdapat perbedaan, yaitu masing-masing pemerintah daerah telah mendapatkan fasilitas yang sama atau merata dari pemerintah pusat yang dapat menunjang peningkatan PDRB setempat.

Tidak hanya pemerintah daerah, pemerintah pusat juga terlibat dalam memenuhi kepentingan masyarakatnya. Pemenuhan kepentingan masyarakat yang dilakukan oleh pemerintah pusat 
adalah bersifat merata, yaitu maksudnya masing-masing pemerintah daerah memiliki fasilitas yang sama sebagai akibat dari kebijakan yang dilakukan oleh pemerintah pusat guna memenuhi kebutuhan masyarakatnya. Adapun fasilitas yang diberikan oleh pemerintah pusat untuk kepentingan umum ini, yaitu seperti jaringan listrik, hal ini sesuai dengan Undang-Undang Nomor 30 tahun 2009 tentang Ketenagalistrikan, yang menyatakan bahwa untuk penyediaan tenaga listrik, pemerintah dan pemerintah daerah menyediakan dana untuk kelompok masyarakat tidak mampu, pembangunan sarana penyediaan tenaga listrik di daerah yang belum berkembang, pembangunan tenaga listrik di daerah terpencil dan perbatasan, pembangunan listrik perdesaan.

Selanjutnya sesuai dengan Peraturan Pemerintah Nomor 16 tahun 2005 tentang Pengembangan Sistem Penyediaan Air Minum, Pemerintah dan Pemerintah Daerah menjamin ketersediaan air baku untuk memenuhi kebutuhan masyarakat agar mendapatkan kehidupan yang sehat, bersih, dan produktif. Selain itu untuk memeratakan kebutuhan masyarakat dalam memenuhi kebutuhan gas dengan adanya subsidi LPG pemerintah juga telah menjalankan program mengenai jaringan gas oleh PT Pertamina dan PT PGN yang akan ditargetkan akan berjalan seperti pemenuhan terhadap air bersih (PDAM), sehingga masyarakat dapat menikmati gas dengan harga yang murah. Dengan adanya berbagai peraturan tersebut, hal ini menandakan pemerintah harus meratakan pemenuhan kebutuhan masyarakat akan air, listrik serta gas, sehingga hal ini membuat pemerintah, baik itu kota maupun kabupaten telah memiliki fasilitas yang sama, yang mana fasilitas-fasilitas ini sangat mempengaruhi produktivitas barang dan jasa. Tanpa adanya listrik, jalan, air dan gas produktivitas barang dan jasa tidak akan berjalan dengan lancar yang dapat menyebabkan tingkat PDRB menjadi rendah, sehingga jelaslah bahwa fasilitas-fasilitas tersebut sangat menunjang peningkatan PDRB.

Oleh karena masing-masing pemerintah daerah kabupaten/kota telah mendapatkan fasilitas yang sama khususnya dalam hal jaringan listrik, jalan, saluran air dan jaringan gas, hal ini menandakan bahwa masing-masing pemerintah daerah telah memiliki faktor pendukung yang sama dalam peningkatan produktivitas barang dan jasa, sehingga menyebabkan tingkat PDRB kabupaten/kota tidak terlalu jauh berbeda.

\subsubsection{Perbedaan nilai Belanja Modal pada pemerintah daerah kabupaten/kota yang beropini WTP dan Non WTP}

Hasil pengujian hipotesis kedua menunjukkan bahwa hipotesis kedua ditolak. Hasil pengujian pada Tabel 1, diperoleh nilai signifikansi (2-tailed) untuk variabel belanja modal sebesar 0,477, dimana nilai tersebut lebih besar dari $0,05(\alpha=5 \%)$. Hasil pengujian untuk hipotesis kedua menunjukkan bahwa tidak ada perbedaan kinerja penyelenggaraan pemerintahan daerah untuk kabupaten/kota se-Sumatera Bagian Selatan, antara pemerintah daerah kabupaten/kota yang memperoleh opini WTP dan Non WTP yang diukur dari indikator belanja modal. Hasil analisis ini konsisten dengan hasil penelitian Taufik (2017), yang menunjukkan bahwa kinerja keuangan pemerintah daerah pada kabupaten/kota se-Sumatera tahun 2007-2011 periode opini WTP_WDP dengan indikator belanja modal tidak lebih dan tidak berbeda dengan kinerja keuangan pemerintah daerah periode opini TW_TMP.

Tingginya total belanja modal yang bersumber dari sumber-sumber keuangan daerah merupakan cerminan baiknya kinerja pemerintah daerah dalam mengelola sumber-sumber keuangan daerah tersebut, yang akan digunakan untuk melakukan pembangunan-pembangunan di daerah tersebut tanpa memiliki ketergantungan yang tinggi pada pemerintah pusat. Adapun kemungkinan penyebab dari tidak adanya perbedaan kinerja penyelenggaraan pemerintahan daerah kabupaten/kota se-Sumatera Bagian Selatan yang memperoleh opini WTP dengan yang memperoleh opini Non WTP dikarenakan pemerintah daerah belum maksimal dalam melihat potensi-potensi daerah yang mereka miliki. Sesuai dengan Undang-Undang Nomor 32 tahun 2004 
menjelaskan bahwa pemerintah daerah dalam mengurus rumah tangganya sendiri diberikan sumber-sumber pendapatan atau penerimaan keuangan daerah untuk membiayai seluruh aktivitas dalam rangka melaksanakan tugas-tugas pemerintah dan pembangunan untuk memenuhi kesejahteraan masyarakat. Adapun sumber-sumber pendapatan yang dimaksud dalam UndangUndang Nomor 32 tahun 2004 pasal 157, yaitu (1) Hasil pajak daerah, misalnya pajak bumi dan bangunan, pajak hotel dan restoran dan lainnya, (2) Hasil Retribusi daerah, misalnya retribusi pelayanan ke pelabuhan, retribusi tempat rekreasi dan olahraga, retribusi pasar grosir/pertokoan dan lainnya, (3) Hasil pengelolaan kekayaan yang dipisahkan, misalnya membentuk perusahaanperusahaan daerah seperti Bank Pembangunan Daerah (BPD), Perusahaan Daerah Air Minum (PDAM), Perusahaan Daerah Angkutan Kota (bus kota) dan lainnya, (4) Lain-lain PAD yang sah, misalnya hasil penjualan kekayaan daerah, hasil penjualan dan/atau pengadaan barang dan/atau jasa oleh daerah dan lainnya.

Keberhasilan pemerintah daerah dalam mendeteksi dan mengelola potensi-potensi yang mereka miliki dapat dilihat dari total pendapatan yang murni dari masing-masing pemerintah daerah itu sendiri, yang merupakan salah satu sumber dana yang akan digunakan dalam belanja modal tanpa melibatkan dana transfer yang berasal dari pemerintah pusat.

Untuk Pemerintah Provinsi Sumatera Selatan yang merupakan provinsi terbesar kedua di Pulau Sumatera setelah Provinsi Sumatera Utara yang dananya bersumber dari pemerintah daerah setempat pada tahun 2016, yaitu sebesar Rp 2.546.177.544.349, dimana jumlah pengeluaran ini masih rendah jika dibandingkan dengan provinsi lain yang luas wilayahnya jauh lebih kecil dari Provinsi Sumatera Selatan, seperti Provinsi Jawa Timur yang dananya bersumber dari pemerintah daerah setempat pada tahun 2016 mencapai Rp 15.817.795.024.797.

Hal ini menunjukkan bahwa pemerintah daerah di Sumatera Bagian Selatan belum terlalu mendeteksi dan belum mengelola potensi-potensi yang mereka miliki secara optimal. Seharusnya dengan luas wilayah yang lebih besar, pemerintah daerah di Sumatera Bagian Selatan ini lebih memiliki potensi-potensi keuangan yang lebih besar pula, yang dapat meningkatkan belanja daerah jika dibandingkan dengan provinsi lainnya yang luas wilayahnya jauh lebih kecil. Akan tetapi dari informasi di atas yang bersumber dari laporan APBD antara Provinsi Sumatera Selatan dengan Provinsi Jawa Timur dapat menunjukkan bahwa Provinsi Sumatera Selatan belum mampu mendeteksi potensi yang dimiliki dan belum mampu mengelolanya dengan baik begitu pun untuk provinsi lainnya yang ada di Sumatera Bagian Selatan, padahal Provinsi Jawa Timur memiliki luas wilayah yang lebih kecil jika dibandingkan dengan provinsi di Sumatera Bagian Selatan, akan tetapi Provinsi Jawa Timur dapat menghasilkan dana yang bersumber dari pemerintah daerahnya sendiri jauh lebih besar dibandingkan provinsi-provinsi di Sumatera Bagian Selatan.

Hal ini menunjukkan bahwa Provinsi Jawa Timur dapat mendeteksi dan mengelola potensi yang mereka miliki dengan baik. Apabila pemerintah daerah di Sumatera Bagian Selatan dapat mendeteksi potensi yang mereka miliki kemudian mampu mengelolanya dengan baik, maka hal ini dapat meningkatkan pendapatan daerah yang kemudian dapat digunakan untuk belanja daerah yang salah satunya, yaitu belanja modal, yang akan digunakan dalam rangka melakukan pembangunan-pembangunan guna meningkatkan pelayanan kepada masyarakat. Di sini pemerintah daerah tidak cukup apabila hanya mengandalkan sumber-sumber pendapatan daerah yang sudah ada saja, tetapi perlu memiliki inovasi dalam menciptakan sumber-sumber pendapatan yang baru. Oleh karena belum optimalnya pendeteksian dan pengelolaan potensi-potensi yang dimiliki oleh masing-masing pemerintah daerah di Sumatera Bagian Selatan, ini menyebabkan tidak terdapatnya perbedaan belanja modal pada masing-masing pemerintah daerah tersebut atau dengan kata lain realisasi belanja modal masing-masing pemerintah daerah di Sumatera Bagian 
Selatan hampir sama. Hal ini menandakan bahwa kinerja pemerintah daerah di Sumatera Bagian Selatan dalam mengelola potensi yang mereka miliki pun tidak jauh berbeda.

\subsubsection{Perbedaan nilai APM pada pemerintah daerah kabupaten/kota yang beropini WTP dan Non WTP}

Hasil pengujian hipotesis ketiga menunjukkan bahwa hipotesis ketiga ditolak. Hasil pengujian pada Tabel 1, diperoleh nilai signifikansi (2-tailed) untuk variabel APM sebesar 0,032, dimana nilai tersebut lebih kecil dari $0,05(\alpha=5 \%)$. Hasil pengujian untuk hipotesis ketiga menunjukkan bahwa terdapat perbedaan kinerja penyelenggaraan pemerintahan daerah untuk kabupaten/kota se-Sumatera Bagian Selatan, antara pemerintah daerah kabupaten/kota yang memperoleh opini WTP dan Non WTP yang diukur dari indikator APM. Jika dilihat dari Output Rank, dapat diketahui bahwa nilai mean untuk indikator APM pemerintah daerah yang memperoleh opini WTP lebih besar dari pada pemerintah daerah yang memperoleh opini Non WTP, yaitu 58,89 > 45,91. Artinya pemerintah daerah yang memperoleh opini WTP memiliki kinerja penyelenggaraan pemerintahan yang lebih baik dibandingkan dengan pemerintah daerah yang memperoleh opini Non WTP melalui indikator APM, dengan selisih mean sebesar 5,77.

Nilai APM yang tinggi merupakan gambaran baiknya kinerja pemerintah daerah dalam memberikan layanan kepada masyarakat khususnya dalam bidang pendidikan. Tingkat APM menggambarkan keberhasilan pemerintah dalam memberikan pelayanan pendidikan kepada masyarakat yang dilihat dari kemudahan masyarakat dalam mengakses layanan yang diberikan pemerintah dan ratanya pendidikan pada anak usia sekolah di suatu daerah. APM yang tinggi menandakan bahwa telah mudahnya masyarakat dalam menikmati atau mendapatkan pelayanan pendidikan yang diberikan oleh pemerintah daerah setempat serta pendidikan untuk anak usia sekolah di daerah tersebut telah rata, maksudnya, yaitu layanan pendidikan yang diberikan pemerintah pada daerah tersebut telah dapat dirasakan oleh seluruh anak usia sekolah atau dengan kata lain semua anak usia sekolah telah mengenyam pendidikan atau tidak mengalami putus sekolah. Hal ini menandakan bahwa pemerintah daerah telah berhasil memenuhi kepentingan pendidikan masyarakat setempat melalui caranya sendiri, yaitu melalui belanja daerah yang salah satunya adalah belanja pendidikan yang digunakan untuk memberikan pelayan kepada masyarakat dalam bidang pendidikan.

Opini audit menurut Undang-Undang Nomor 15 Tahun 2004 tentang Pemeriksaan Pengelolaan dan Tanggung Jawab Keuangan Negara merupakan pernyataan profesional sebagai kesimpulan pemeriksaan mengenai tingkat kewajaran informasi yang disajikan dalam LK yang didasarkan pada (1) Kesesuaian dengan standar akuntansi pemerintahan, (2) Kecukupan pengungkapan, (3) Kepatuhan terhadap undang-undang dan (4) Efektivitas sistem pengendalian intern. Artinya opini audit menggambarkan kualitas dari laporan keuangan sebagai suatu bentuk kepercayaan publik terhadap kredibilitas dan kehandalan informasi yang terkandung dalam laporan keuangan pemerintah daerah.

Opini WTP menandakan kualitas laporan keuangan pemerintah daerah telah baik, angka-angka yang tercantum dalam laporan keuangan, baik itu pendapatan maupun belanja yang direalisasikan telah dapat dipercaya sesuai dengan bukti-bukti pendukungnya, sehingga sudah sewajarnya jika pemerintah daerah yang memperoleh opini WTP dapat memberikan pelayanan yang lebih baik dari pemerintah daerah yang memperoleh opini Non WTP, yang dapat tercermin dari tingginya nilai APM. Dengan melihat mean untuk pemerintah daerah yang memperoleh opini WTP lebih tinggi sebesar 5,77 dari Non WTP menandakan bahwa pemerintah daerah yang memperoleh opini WTP telah memiliki kinerja penyelenggaraan yang baik dalam memberikan pelayanan di bidang pendidikan. Artinya dana belanja pendidikan yang terdapat dalam laporan realisasi APBD telah disalurkan atau telah digunakan sebagaimana mestinya seperti untuk pembangunan dan renovasi 
sekolah, pembangunan perpustakaan, pembelian buku-buku dan peralatan-peralatan sekolah yang dapat memfasilitasi kegiatan belajar dan mengajar, selain itu juga pelayanan pendidikan yang diberikan pemerintah daerah, yaitu berupa pemberian beasiswa bagi anak usia sekolah yang bermasalah dalam hal financial, sehingga mereka dapat melanjutkan sekolah dan mengenyam pendidikan tanpa harus merasakan putus sekolah akibat dari tingginya biaya pendidikan. Dengan demikian sudah sewajarnya terdapat perbedaan kinerja penyelenggaraan pemerintah daerah yang memperoleh opini WTP dengan Non WTP yang dibandingkan melalui kemudahan masyarakat dalam mengakses pelayanan pendidikan, yaitu APM sebagai bentuk keberhasilan pemerintah daerah dalam memenuhi kepentingan masyarakat dalam bidang pendidikan.

\subsubsection{Perbedaan nilai EKPPD pada pemerintah daerah kabupaten/kota yang beropini WTP dan Non WTP}

Hasil pengujian hipotesis keempat menunjukkan bahwa hipotesis keempat ditolak. Hasil pengujian pada Tabel 1, diperoleh nilai signifikansi (2-tailed) untuk variabel EKPPD sebesar 0,133 , dimana nilai tersebut lebih besar dari $0,05(\alpha=5 \%)$. Hasil pengujian untuk hipotesis keempat menunjukkan bahwa tidak ada perbedaan kinerja penyelenggaraan pemerintahan daerah untuk kabupaten/kota se-Sumatera Bagian Selatan, antara pemerintah daerah kabupaten/kota yang memperoleh opini WTP dan Non WTP yang diukur dari indikator EKPPD. Hasil analisis ini tidak konsisten dengan hasil penelitian Yasmin (2016), yang menyatakan bahwa Kinerja Pemerintah Kabupaten/Kota se-Indonesia yang beropini WTP dengan indikator EKPPD berbeda secara signifikan dengan Pemerintah Kabupaten/Kota se-Indonesia yang Non WTP. Namun hasil penelitian ini konsisten dengan penelitian yang dilakukan Heriningsih (2015) kinerja penyelenggara pemerintah daerah secara statistik menunjukkan tidak terdapat perbedaan antara kabupaten/kota yang memiliki opini WTP dengan yang memperoleh opini selain WTP.

Nilai EKPPD yang tinggi merupakan gambaran baiknya kinerja aparatur daerah dalam menjalankan tanggung jawab yang diberikan kepadanya dalam memenuhi segala kepentingan masyarakat setempat. Adapun penyebab dari tidak adanya perbedaan kinerja penyelenggaraan pemerintahan daerah kabupaten/kota se-Sumatera Bagian Selatan yang memperoleh opini WTP dengan yang memperoleh opini Non WTP melalui indikator EKPPD, yaitu dikarenakan pemerintah daerah kabupaten/kota di Sumatera Bagian Selatan memiliki keseragaman skor EKPPD atau bisa dikatakan pemerintah daerah memiliki selisih skor yang tidak jauh berbeda. Berdasarkan Peraturan Pemerintah Nomor 6 Tahun 2008, indikator yang digunakan dalam memberikan skor EKPPD terdiri dari Indeks Capaian Kinerja dan Indeks Kesesuaian Materi, yang mana dua hal ini akan dievaluasi oleh tim EPPD untuk masing-masing pemerintah daerah kemudian akan diberikan skor. Jika dilihat indikator yang digunakan untuk menentukan skor EKPPD yang tercantum dalam Peraturan Pemerintah Nomor 6 Tahun 2008 berbeda dengan indikator yang digunakan BPK yang digunakan sebagai dasar untuk memberikan opini audit terhadap laporan keuangan pemerintah daerah. Adapun indikator yang digunakan oleh BPK dalam menentukan opini WTP dan selain WTP untuk masing-masing pemerintah daerah, yaitu diatur dalam Undang-Undang Nomor 15 Tahun 2004 tentang Pemeriksaan Pengelolaan dan Tanggung jawab Keuangan Negara, yang didasarkan pada (1) Kesesuaian dengan standar akuntansi pemerintahan, (2) Kecukupan pengungkapan, (3) Kepatuhan terhadap undang-undang dan (4) Efektivitas sistem pengendalian intern. Hal ini menandakan indikator yang digunakan dalam pemberian skor EKPPD berbeda dengan indikator opini audit, opini audit lebih menggambarkan bagaimana kualitas laporan keuangan pemerintah daerah sedangkan skor EKPPD lebih menggambarkan bagaimana kinerja dari aparatur daerah.

Jika dilihat skor EKPPD untuk pemerintah daerah kabupaten/kota se-Sumatera Bagian Selatan untuk tahun 2015 dan 2016 rata-rata telah memiliki skor di atas 2 (status "Tinggi"). Artinya pemerintah daerah kabupaten/kota se-Sumatera Bagian Selatan tersebut telah memiliki kinerja 
yang baik sesuai dengan hasil evaluasi yang dilakukan oleh tim EPPD berdasarkan pada indikatorindikator yang telah ditetapkan. Oleh karena keseragaman dan selisih skor EKPPD yang tidak begitu jauh antara pemerintah kabupaten/kota di Sumatera Bagian Selatan, menyebabkan hasil penelitian ini menunjukkan tidak adanya perbedaan kinerja penyelenggaraan pemerintahan daerah kabupaten/kota se-Sumatera Bagian Selatan yang memperoleh opini WTP dengan yang memperoleh opini Non WTP yang dibandingkan dengan menggunakan indikator EKPPD.

\subsubsection{Perbedaan nilai IPM pada pemerintah daerah kabupaten/kota yang beropini WTP dan Non WTP}

Hasil pengujian hipotesis kelima menunjukkan bahwa hipotesis kelima ditolak. Hasil pengujian pada Tabel 1, diperoleh nilai signifikansi (2-tailed) untuk variabel IPM sebesar 0,977, dimana nilai tersebut lebih besar dari $0,05(\alpha=5 \%)$. Hasil pengujian untuk hipotesis kelima menunjukkan bahwa tidak ada perbedaan kinerja penyelenggaraan pemerintahan daerah untuk kabupaten/kota se-Sumatera Bagian Selatan, antara pemerintah daerah kabupaten/kota yang memperoleh opini WTP dan Non WTP yang diukur dari indikator IPM.

Nilai IPM merupakan gambaran dari keberhasilan pemerintah dalam menyejahterakan masyarakatnya yang diukur dari tingkat kesehatan, pendidikan dan pendapatan masyarakat setempat. Adapun kemungkinan penyebab dari tidak adanya perbedaan kinerja penyelenggaraan pemerintahan daerah kabupaten/kota se-Sumatera Bagian Selatan yang memperoleh opini WTP dengan yang memperoleh opini Non WTP dengan menggunakan indikator IPM, yaitu dikarenakan telah adanya tanggung jawab yang sama untuk pemerintah pusat dan masing-masing pemerintah daerah, yaitu dalam menyediakan rumah sakit berdasarkan kebutuhan masyarakat serta menjamin pembiayaan pelayanan kesehatan di rumah sakit bagi fakir miskin, atau orang tidak mampu (Undang-Undang Nomor 44 tahun 2009), sehingga dibentuk 14 Rumah Sakit Rujukan Nasional serta dibentuk juga 184 Rumah Sakit Rujukan Regional, Khusus untuk daerah terpencil dibangunkan Rumah Sakit kelas D Pratama dengan kapasitas 50 tempat tidur.

Selain itu terdapat juga kebijakan-kebijakan dari pemerintah pusat seperti Program Indonesia Sehat, Kartu Indonesia Sehat (KIS) dengan menyiapkan 6.000 Puskesmas di 6 regional, Kartu Indonesia Sehat (KIS), yaitu program kesehatan yang menjamin masyarakat yang kurang mampu untuk dapat mendapatkan pelayanan kesehatan dan program Nusantara Sehat (NS), yaitu dilakukan peningkatan jumlah, sebaran, komposisi dan mutu Nakes pada tim yang memiliki latar belakang yang berbeda mulai dari dokter, perawat dan Nakes lainnya. Kebijakan-kebijakan dalam bidang kesehatan ini merupakan sebagai bentuk upaya mewujudkan masyarakat Indonesia berperilaku sehat, hidup dalam lingkungan yang sehat dan mampu menjangkau pelayanan kesehatan yang bermutu untuk mencapai derajat kesehatan yang setinggi-tingginya.

Pemerintah sangat dituntut untuk meningkatkan pendidikan di negara ini sesuai dengan UUD 1945 pasal 31 ayat (1) yang berbunyi: "tiap-tiap warga negara berhak mendapatkan pengajaran," serta Undang-Undang Nomor 20 tahun 2003 pasal 5 ayat (1) tentang Sistem Pendidikan Nasional yang menegaskan bahwa "setiap warga negara mempunyai hak yang sama untuk memperoleh pendidikan yang bermutu dan pada pasal 6 ayat (1) dinyatakan bahwa setiap warga negara yang berusia tujuh tahun sampai lima belas tahun wajib mengikuti pendidikan dasar.", sehingga dengan ditetapkannya peraturan ini dapat dipastikan bahwa pemerintah pusat memiliki tanggung jawab untuk memperhatikan pendidikan di negara ini dengan memberikan pelayanan pendidikan kepada masyarakat untuk masing-masing daerah melalui pemerintah daerah setempat. Untuk meningkatkan kualitas pendidikan negara ini, pemerintah telah menerapkan berbagai macam kebijakan seperti di dalam Peraturan Pemerintah Nomor 47 tahun 2008 tentang Wajib Belajar, menyatakan bahwa wajib belajar diselenggarakan pada jalur pendidikan formal, pendidikan non formal dan pendidikan informal. Program wajib belajar 
selama 9 tahun ini mewajibkan anak-anak untuk bersekolah hingga jenjang sekolah pertama/sederajat tanpa dibebankan biaya sekolah, selain itu terdapat juga bantuan dana BOS (Bantuan Operasional Sekolah) yang digunakan untuk memberikan fasilitas-fasilitas sekolah, pembelian buku dan peralatan sekolah serta sejumlah dana bagi anak yang tergolong dari keluarga yang kurang mampu, serta program beasiswa bagi murid yang berprestasi, tetapi memiliki kekurangan dalam bidang finansial serta Program Indonesia Pintar (PIP) dengan mendistribusikan Kartu Indonesia Pintar (KIP). Semua program-program pemerintah ini dilakukan secara nasional, artinya seluruh anak usia sekolah mendapatkan fasilitas yang sama dari pemerintah atau dengan kata lain semua fasilitas-fasilitas ini diberikan secara merata, sehingga setiap anak usia sekolah sebagaimana yang ditetapkan dalam peraturan dapat memperoleh pelayanan pendidikan secara merata.

Dalam meningkatkan pendapatan masyarakat pemerintah berupaya untuk dapat meningkatkan produktivitas masyarakat, adapun program yang tengah dikembangkan oleh pemerintah yakni Program Nasional Pemberdayaan Masyarakat (PNPM), pengembangan usaha kecil dan koperasi, penyediaan infrastruktur di daerah pedesaan, dan program bantuan pelatihan dan manajemen dan pemberian Bantuan Langsung Tunai (BLT). Melalui program-program yang diberikan oleh pemerintah ini dapat membantu seluruh masyarakat yang ada di Indonesia dalam meningkatkan produktivitasnya, tidak hanya di perkotaan semata, tetapi hingga juga ke daerah pedesaan. Melalui program-program pemerintah ini juga, seluruh masyarakat dapat memiliki kesempatan yang sama untuk membuka usaha serta meningkatkan produktivitasnya melalui bekal ilmu yang diberikan oleh pemerintah melalui program bantuan pelatihan dan manajemen.

Dengan telah diterapkannya program-program tersebut, yaitu untuk kesehatan masyarakat, pendidikan serta pendapatan masyarakat secara nasional maka telah membantu masing-masing pemerintah daerah dalam meningkatkan nilai IPM-nya. Dengan diterapkan secara nasional inilah kemungkinan besar nilai IPM masing-masing pemerintah daerah tidak terdapat perbedaan yang begitu signifikan, yang disebabkan karena telah memiliki program yang sama yang berasal dari pusat atau dengan kata lain kebijakan-kebijakan tersebut telah diterapkan secara nasional.

\section{Simpulan}

Berdasarkan penelitian yang dilakukan pada 53 pemerintah daerah kabupaten/kota se-Sumatera Bagian Selatan untuk periode 2015-2016 menghasilkan kesimpulan sebagai berikut:

1. Tidak terdapat perbedaan kinerja penyelenggaraan pemerintahan daerah untuk kabupaten/kota se-Sumatera Bagian Selatan yang memperoleh opini WTP dengan Non WTP, yang dibandingkan dengan menggunakan indikator PDRB. Hal ini dikarenakan jumlah pengeluaran yang digunakan untuk pembangunan oleh masing-masing pemerintah daerah kabupaten/kota se-Sumatera Bagian Selatan periode 2015-2016 tidak jauh berbeda, sehingga menyebabkan jumlah permintaan barang dan jasanya pun tidak jauh berbeda. Faktor selanjutnya yang mengakibatkan tidak terdapatnya perbedaan kinerja penyelenggaraan pemerintahan daerah yaitu telah adanya pemenuhan kepentingan umum yang dilakukan secara merata. Artinya masing-masing pemerintah daerah telah memberikan fasilitas umum kepada masyarakatnya, yaitu seperti jaringan listrik, jalan, saluran air, jaringan gas dan sebagainya yang dapat menunjang produktivitas masyarakat terhadap barang dan jasa.

2. Tidak terdapat perbedaan kinerja penyelenggaraan pemerintahan daerah untuk kabupaten/kota se-Sumatera Bagian Selatan yang memperoleh opini WTP dengan Non WTP, melalui indikator belanja modal yang bersumber dari PAD. Hal ini dikarenakan pemerintah daerah untuk kabupaten/kota se-Sumatera Bagian Selatan belum maksimal dalam mendeteksi dan mengelola potensi-potensi daerah yang mereka miliki, pemerintah daerah hanya mengandalkan sumber-sumber pendapatan daerah yang sudah ada saja. 
Padahal jika pemerintah daerah dapat lebih mengoptimalkan pendeteksian terhadap potensipotensi keuangan yang mereka miliki serta mampu mengelolanya dengan baik, hal ini dapat meningkatkan pendapatan daerah yang akan mengakibatkan realisasi belanjanya juga akan ikut meningkat, sehingga akan membuat kepentingan masyarakat setempat dapat semakin terpenuhi.

3. Terdapat perbedaan kinerja penyelenggaraan pemerintahan daerah untuk kabupaten/kota seSumatera Bagian Selatan yang memperoleh opini WTP dengan Non WTP melalui indikator APM dengan selisih mean 5,77. Hal ini menunjukkan bahwa pemerintah daerah untuk kabupaten/kota se-Sumatera Bagian Selatan yang memperoleh opini WTP memiliki kinerja penyelenggaraan yang baik dibandingkan dengan pemerintah daerah yang memperoleh opini Non WTP, yang dibandingkan dengan keberhasilan pemerintah daerah dalam memberikan pelayanan kepada masyarakat khususnya di bidang pendidikan.

4. Tidak terdapat perbedaan kinerja penyelenggaraan pemerintahan daerah untuk kabupaten/kota se-Sumatera Bagian Selatan yang memperoleh opini WTP dengan Non WTP melalui indikator EKPPD. Hal ini dikarenakan pemerintah daerah kabupaten/kota seSumatera Bagian Selatan hampir memiliki keseragaman skor EKPPD dengan selisih yang tidak begitu jauh, sehingga menunjukkan tidak adanya perbedaan kinerja penyelenggaraan pemerintahan daerah yang memperoleh opini WTP dengan Non WTP yang menggunakan indikator EKPPD.

5. Tidak terdapat perbedaan kinerja penyelenggaraan pemerintahan daerah untuk kabupaten/kota se-Sumatera Bagian Selatan yang memperoleh opini WTP dengan Non WTP melalui indikator IPM. Hal ini dikarenakan telah adanya kebijakan ataupun program dari pemerintah pusat untuk meningkatkan kesehatan, pendidikan dan pendapatan masyarakat yang diterapkan secara nasional, sehingga ketiga permasalahan ini telah mendapatkan perhatian dan penanganan secara merata. Hal ini membuat tidak adanya perbedaan kinerja penyelenggaraan pemerintahan daerah yang memperoleh opini WTP dengan Non WTP melalui indikator IPM.

\section{Daftar Pustaka}

Badan Pemeriksa Keuangan Republik Indonesia. (2016). Ikhtisar Hasil Pemeriksaan Semester II Tahun 2016. Jakarta: BPK

Badan Perencanaan Pembangunan Nasional (Bappenas). (2014). United Nations Development Programme (UNDP). Studi Evaluasi Dampak Pemekaran Daerah 2001-2007. Building and Reinventing Decentralised Governance (BRIDGE).

Badan Pusat Statistik. (2016). Produk Domestik Regional Bruto Kabupaten/Kota di Indonesia tahun 2012-2016. Jakarta: BPS.

Badan Pusat Statistika. (2016). Indeks Pembangunan Manusia. Jakarta: BPS

Ghozali, I. \& Chariri, A. (2007). Teori Akuntansi. Semarang: Badan Penerbit UNDIP.

Direktorat Jenderal Perimbangan Keuangan Kementrian Keuangan. 2017. Realisasi APBD 2016. Jakarta: DJPK Kemenkeu.

Heriningsih, S. (2015). Analisis Kinerja Penyelenggara Pemerintah Daerah dan Tingkat Korupsi Dianalisis dari Opini Auditor. University Research Colloquium UPN Veteran Yogyakarta 2015: 86-95.

Kementerian Pendidikan dan Kebudayaan (Kemendikbud). (2016). Angka Partisipasi Murni tahun 2016. Jakarta: Kemendikbud.

Kementerian Pendidikan dan Kebudayaan (Kemendikbud). (2016). Analisis Kinerja Pendidikan Provinsi Bengkulu. Kementerian Pendidikan dan Kebudayaan Pusat Data dan Statistik Pendidikan dan Kebudayaan. Jakarta: Kemendikbud.

Kompas. (2017). Ketika Opini Audit BPK Tak Lagi Bermakna. KOMPAS, 31 Mei 2017 [Online] (Diakses 
http://bisniskeuangan.kompas.com/read/2017/05/31/090000426/ketika.opini.audit.bpk.t ak.lagi.bermakna, 19 Februari 2018).

Republik Indonesia. (1945). Undang-Undang Dasar 1945. Indonesia, Jakarta.

Sekretariat Negara.

(1946). Kitab Undang-Undang Hukum Pidana (KUHP). Jakarta:

. (1999). Undang-Undang Nomor 22 Tahun 1999 tentang Otonomi Daerah.

Indonesia, Jakarta.

. (2003). Undang-Undang Nomor 20 Tahun 2003 tentang Sistem Pendidikan

Nasional. Jakarta: Departemen Pendidikan Nasional.

.(2004). Undang-Undang Nomor 15 Tahun 2004 tentang Pemeriksaan

Pengelolaan dan Tanggung Jawab Keuangan Negara. Jakarta: Sekretariat Negara.

(2004). Undang-Undang Nomor 32 Tahun 2004 tentang Pemerintah

Daerah. Jakarta: Sekretariat Negara.

(2005). Peraturan Pemerintah Nomor 16 Tahun 2005 tentang

Pengembangan Sistem Penyediaan Air Minum. Jakarta: BPKP.

(2007). Peraturan Pemerintah Nomor 3 Tahun 2007 tentang Laporan

Penyelenggaraan Pemerintahan Daerah Kepada Pemerintah, Laporan Keterangan

Pertanggungjawaban Kepala Daerah Kepada Dewan Perwakilan Rakyat Daerah, dan

Informasi Laporan Penyelenggaraan Pemerintahan Daerah Kepada Masyarakat.

Jakarta: DJPK-Kemenkeu.

(2008). Peraturan Pemerintah Nomor 6 tahun 2008 tentang Pedoman

Evaluasi Penyelenggaraan Pemerintah Daerah. Jakarta: DJPK-Kemenkeu.

(2008). Peraturan Pemerintah Nomor 47 Tahun 2008 tentang Wajib

Belajar. Jakarta: BPKP.

(2009). Undang-Undang Nomor 30 Tahun 2009 tentang Ketenagalistrikan.

Jakarta: Kementerian ESDM RI.

(2009). Undang-Undang Nomor 44 Tahun 2009 tentang Rumah Sakit.

Jakarta: Depkes.

(2013). Undang-Undang Nomor 17 Tahun 2013 tentang Keuangan Negara.

Jakarta: Sekretariat Negara.

(2014. Undang-Undang Nomor 23 Tahun 2014 tentang Pemerintahan

Daerah). Jakarta: Sekretariat Negara.

(2016. Keputusan Menteri Dalam Negeri Republik Indonesia

(Kepmendagri) Nomor: 120-10421 Tahun 2016 tentang Penetapan Peringkat dan Status

Kinerja Penyelenggaraan Pemerintahan Daerah Nasional Tahun 2015. Jakarta: Kemendagri.

(2018). Keputusan Menteri Dalam Negeri Republik Indonesia (Kepmendagri) Nomor: 100-53 Tahun 2018 tentang Penetapan Peringkat dan Status Kinerja Penyelenggaraan Pemerintahan Daerah Nasional Tahun 2016. Jakarta: Kemendagri.

(2018). Peraturan Menteri Pendidikan dan Kebudayaan Republik Indonesia Nomor 18 Tahun 2018 tentang Petunjuk Teknis Bantuan Operasional Sekolah. Jakarta: Kemendikbud.

Sugiyono. (2016). Metode Penelitian Kuantitatif Kualitatif dan R\&D. Bandung: Alfabeta.

Taufik. (2017). Analisis Perbandingan Kinerja Keuangan Pemerintah Kabupaten Kota seSumatera. Jurnal Ilmiah Gema Ekonomi, 7(1): 993-1012.

Verawaty. (2014). The Accessibility Determinants of Internet Financial Reporting of Local Government: Further Evidence from Indonesia. World Review of Business Research, 4(2): 176-195.

Verawaty. (2017). Accountability and Internet Financial Reporting of Local Government: An Indonesia Analysis. Saarbrüchen: Lambert Academic Publishing. 
Verawaty. (2017). Determinan Transparansi Informasi Keuangan Daerah melalui E-government Pemerintah Daerah di Sumatera Selatan. Akuisisi, 13(2): 92-107.

Verawaty, Puspanita, I., \& Sularti, E. (2019). Pengaruh BPK, Karakteristik Pemerintah dan Indeks Pembangunan Manusia terhadap Tingkat Korupsi Pemerintah Daerah di Indonesia. MBiA, 18(2): 79-99.

Verawaty, Jaya, A.K., Puspanita, I., \& Nurhidayah (2020). Pengaruh PAD dan Dana Perimbangan terhadap Kinerja Keuangan Pemerintah Kabupaten/Kota di Sumatera Selatan. MBiA, 19(1): 21-37.

Yasmin, A. (2016). Perbandingan Kinerja Pemerintah Kabupaten/Kota yang Memperoleh Opini WTP dan Non WTP. Tesis. Universitas Lampung.

\section{Copyright Disclaimer}

Copyright for this article is retained by the author(s), with first publication rights granted to the journal. 